\title{
AUDIT QUALITY AND EARNINGS MANAGEMENT: EVIDENCE FROM TURKEY
}

\author{
Ahmet ÖZCAN ${ }^{1}$
}

\begin{abstract}
Earnings management is one of the controversial issues in the current business environment. The value relevance of earnings is adversely influenced by earnings management. The objective of this study is to analyze the association between audit quality and earnings management for non-financial firms quoted on Borsa Istanbul. Ordinary least square regression analysis is employed in this study in analyzing the association between earnings management and audit quality. Three different proxies for audit quality (auditor independence, audit industry specialization and auditor tenure) were analyzed based on a sample of 97 nonfinancial firms quoted on Borsa Istanbul from 2013 to 2018. Empirical analysis indicates that auditor independence and audit industry specialization are significantly negatively related with likelihood of earnings management and long-term auditor and client relationship enables the management of firms to more actively engage in earnings management. This paper finds support for the notion that the high-quality audit is one of the prominent factors that can mitigate earnings management practices.
\end{abstract}

Keywords: Audit Quality, Earnings Management, Financial Reporting JEL Classifications: M40, M41, M42

\section{DENETIM KALITESI VE KAZANÇ YÖNETIMI: TÜRKIYE'YE ILIŞKIN BULGULAR}

\section{Öz}

Kazanç yönetimi iş dünyasında en fazla tartışılan konular arasındadır. Kazançların değer ilgililiği kazanç yönetiminden olumsuz olarak etkilenmektedir. Bu çalışmanın amacı, denetim kalitesi ve kazanç yönetimi arasındaki ilişkiyi Borsa İstanbul'a kote olan şirketler açısından analiz etmektir. Denetim kalitesi ve kazanç yönetimi arasındaki ilişki sıradan en küçük kareler yöntemi kullanılarak analiz edilmektedir. 2013-2018 yıllarını kapsayan ve Borsa İstanbul'a kote olan 97 reel sektör firmasının verilerinden yararlanarak denetim kalitesinin üç göstergesi (denetçi bağımsızlığı, denetçinin sektörel uzmanlığı ve denetim firmasının müşteri firmaya hizmet süresi) sıradan en küçük kareler yöntemi kullanılarak analiz edilmektedir. Sıradan en küçük kareler yönteminin sonuçlarına göre; denetçi bağımsızlığı ve denetçinin sektörel uzmanlığı kazanç yönetimini önemli derecede azaltmaktadır ve denetim firması ile müşteri firma arasındaki uzun süreli ilişki, müşteri firmanın daha yoğun bir şekilde kazanç yönetimini uygulamasına yol açmaktadır. Bunlara ek olarak, bağımsız denetiminin kalitesinin yüksek olması firmaların kazanç yönetimi uygulamalarını önemli derecede azaltmaktadır.

Anahtar Kelimeler: Denetim Kalitesi, Kazanç Yönetimi, Finansal Raporlama

JEL SInıflandırması: M40, M41, M42

${ }^{1}$ Doktor Öğretim Üyesi, Yönetim Bilişim Sistemleri, İşletme Fakültesi, Adana Alparslan Türkeş Bilim ve Teknoloji Üniversitesi, aozcan@adanabtu.edu.tr, ORCID:0000-0002-9021-6096 


\section{Introduction}

Investors, creditors and stockholders pay close attention to earnings. Financial statements that show the firms' financial position and performance are regarded as a prominent source of information to firms' stakeholders. In the financial reporting process, the audit firm is considered an important third party that can effectively decrease asymmetric information between firm management and stockholders (Mansi et al., 2004).

The relationship between earnings management and audit quality has significantly grabbed the attention of creditors, investors and government authorities following high-profile corporate frauds. DeFond and Francis (2005) state that adverse impacts of corporate frauds have revealed the importance of independent audits in the business environment. Auditors are tasked with protecting the stakeholders' interest.

The audit quality can be described as the joint probability that the auditor uncovers financial statement frauds and then disclose them to the stakeholders of the firm (DeAngelo, 1981). Highprofile corporate frauds have raised important questions about audit quality. A growing number of financial market participants claim that audit firms themselves are to blame for their audit quality problems. The effectiveness of auditing in constraining earnings management strongly depends on the quality of auditing process. High-quality auditors are more likely to uncover earnings management practiced by firms than low-quality auditors (Becker et al., 1998). It is also worth mentioning that high-quality auditors tend to play more active roles in the deterrence of earnings management since the reputation of high- quality audit firms can be severely damaged if financial misreporting is detected. Audit quality strongly depends on independence and experience of auditors. Such extensive knowledge and experience enable auditors to detect accounting irregularities in highly complex cases (Habbash and Alghamdi, 2017). A well-regulated financial system and higher level of auditor independence significantly contribute to decreasing earnings management practices. Additionally, higher level of transparency requirements in financial reporting process considerably reduces the earnings management practices (Hunton et al., 2006).

In the aftermath of corporate frauds such as Enron, Parmalat and WorldCom, regulatory agencies have mounted pressure on audit firms to increase the audit quality. Higher audit quality significantly increases the integrity of the firms' financial reporting system. Higher audit quality contributes to the monitoring mechanisms that can promote the quality of firms' financial reporting process. In the competitive economic environment, auditors should effectively cope with earnings management that distorts the true financial position and performance of the firm.

Since the firm value is positively influenced by reported earnings, it may put pressure on the firm management to engage in earnings management (Lin et al., 2006). Earnings management does not necessarily mean financial statement fraud. Dechow and Skinner (2000) state that a firm's management can use aggressive and conservative accounting choices allowed by International Financial Reporting Standards (IFRS) to engage in earnings management. On the contrary, financial statement fraud is the use of accounting choices that do not conform to IFRS. Firms may engage in earnings management by the exercise of accounting choices with an objective to achieve a specific purpose. Earnings management can cause significant asymmetric information between stockholders and firm management. The investigation of audit firms' impact in the detection of earnings management can provide vital implications to regulatory agencies and standard setting bodies.

The ultimate objective of this paper is to contribute to the previous literature by analyzing whether audit quality improves the quality of firms' financial statements. The sample used in the empirical analysis consists of non-financial firms listed on Borsa Istanbul during the period 20132018. Ordinary least squares regression analysis is used to analyze the association between audit quality and earnings management. Consistent with my hypothesis, empirical results indicate that 
a high audit quality can decrease the likelihood that the management of firms engage in earnings management.

The rest of this study is structured as follows. The next section presents the previous literature and hypothesis development. The third section puts forward the research design. Section 4 reports the empirical analysis results. The last section presents the conclusion and recommends future studies that can shed more light on the effects of audit quality on earnings management.

\section{Literature Review and Hypothesis Development}

The previous literature on the effect of audit quality on earnings management and research hypotheses are provided in this section. Literature reviews enable us to have a deep understanding of dynamics of earnings management. The present paper focuses on analyzing and discussing the impacts of audit quality on earnings management practices. Therefore, several hypotheses that can determine and relate important aspects of audit quality to earnings management practices are developed. Past experiences have demonstrated that audit quality is one of the multidimensional issues in the ever-changing business world.

Agency theory should be meticulously considered in analyzing the impacts of earnings management practices. Investors, creditors, stockholders and firm management have different interests. Therefore, conflict of interest can emerge among investors, creditors, stockholders and firm management. Earnings management causes an agency cost that adversely influences the functioning of financial markets. Agency costs occur when creditors, stockholders and investors make irrational investment decisions. The management of firms can artificially increase or decrease earnings to maximize its interest. Firms should establish control mechanisms that can decrease agency costs.

Auditor independency is one of the keystones of auditing process (Gill and Cosserat, 1996). High degree of auditor independence ensures better financial reporting process. If auditors are not independent, it is more likely that they will fail to produce high-quality audits. It is predominantly undisputed that high degree of auditor independence enhances the credibility of firms' financial statements (Houghton and Jubb, 2003; Antle, 1984). Regulatory agencies use mandatory auditor rotation to increase auditor independence. Mandatory auditor rotation is also expected to bring a fresh look at the firm's financial statements. Davis et al. (2000) state that a long term auditor and client firm relationship has adverse impacts on auditor independence and enables the management of firms to engage more actively in earnings management. Broadly speaking, there is an inverse relationship between earnings management and auditor independence.

The lack of auditor independence significantly mitigates the quality of audit service (Sweeney, 1994). The strong economic relationship between auditor and client jeopardizes the auditor independence (Magee and Tseng, 1990; Beck et al., 1988). Audit market competition, auditor tenure, corporate governance mechanisms and regulatory framework have prominent impacts on the degree of auditor independency (Beattie et al., 1999; Tepalagul and Lin, 2015). The provision of non-audit services is likely to strengthen the economic relationship between audit firm and its client. Litigation risk is one of important factors that influence auditor independence. When an audit firm fails to detect earnings management practices, it may be subject to serious legal actions initiated by government authorities that may harm its reputation. Hence, high litigation risk is regarded as a vital incentive for audit firms to independently conduct the audit process. Chi et al. (2012) and Hunt and Lulseged (2007) state that Big 4 auditors are more concerned than non-Big 4 auditors about independence. Consistent with Gerayli et al. (2011) and Hodge (2003), it is expected that high degree of auditor independence mitigates the occurrence of earnings management. Thus, the first hypothesis is constructed as follows;

$\mathrm{H} 1$ : There is a negative relationship between auditor independence and earnings management practices. 
In the highly competitive audit market, audit firms should possess specific industry knowledge to satisfy their clients. Krishnan (2003), Balsam et al. (2003) and Chen et al. (2005) state that having specific industry specialization is likely to enhance the quality of auditing process. Using a sample that consists of 1484 publicly traded Australian firms, Craswell et al. (1995) found that industry specialist auditors gain important fee premium and fee premium is positively influenced by audit quality. DeAngelo (1981) stated that specific industry specialization is an important reason for the choosing of Big 5 auditors.

Dunn and Mayhew (2004) reported that auditors with a high level of industry expertise help client firms to enhance the quality of financial statement disclosures. Having industry-specific expertise enables audit firms to constrain client firms' earning management practices and decrease audit risks. Firms having complex business processes demand auditors who have a deep understanding of the characteristics of industry in which firms operate. Audit firms that specialize in the specific industries invest in more information technology, training and development of their employees. Consistent with Zhou and Elder (2001), it is expected that audit industry specialization can constrain the earnings management practices. This discussion enables us to formulate the second hypothesis.

$\mathrm{H} 2$ : There is a negative relationship between audit industry specialization and earnings management practices.

There is a massive debate in the literature whether long audit tenure is related with low or high audit quality. Long audit tenure may enable audit firms to have a very close relationship with their clients. Carcello and Neal (2000) assert that a close relationship between an audit firm and its client may undermine auditor independence and skepticism. Auditor skepticism and independence are inevitable parts of audit quality. Additionally, long audit tenure causes some audit firms to be overreliant on their clients. Mandatory audit rotation is proposed as a solution for low audit quality resulting from long audit tenure.

On the other hand, long audit tenure may enable audit firms to familiarize with financial reporting process and operations of client firms, resulting in increased audit quality. Davis et al. (2002) state that high audit tenure plays a pivotal role in identifying audit risks and conducting high-quality audit process. The long audit tenure allows auditors to get more client specific information about internal control structure, financial reporting process and operational structure (Ghosh and Moon, 2005). It is expected that the long audit tenure enables auditors to effectively detect client firms' earnings management practices. The above discussion leads to the below hypothesis.

$\mathrm{H} 3$ : There is a negative relationship between audit tenure and earnings management practices.

\section{Research Design}

\subsection{Measurement of Earnings Management}

Discretionary accruals are employed to measure sample firms' earnings management practices. Discretionary accruals are non-obligatory accruals determined by the firm management. In the accrual based accounting system, accruals play an important role in the financial reporting system. The structure of total accruals should be examined to capture effects of accounting choices. Nondiscretionary accruals are subtracted from total accruals to compute discretionary accruals. Following Chen et al. (2005), Habbash and Alghamdi (2017) and Gerayli et al. (2011), this study employed Modified Jones Model to detect earnings management. Modified Jones Model vastly outperforms other models in the detection of earnings management practices. Modified Jones Model presumes that any change in credit sales transactions is caused by earnings management practices.

DeFond and Park (1997) and Gul et al. (2003) posit that negative and positive discretionary accruals can be employed by firms' management to hide operating losses or save corporate 
earnings for future periods. The amount of non-discretionary accruals are prominently affected by accounting choices of firms' management. In the Modified Jones Model, non-discretionary accruals are calculated during the accounting period as follows. Research variables used in the Modified Jones Model are deflated by prior year's total assets to eliminate the problems of heteroscedasticity.

$N D A_{i t}=\beta_{1}\left(\frac{1}{T A_{i t-1}}\right)+\beta_{2} \frac{\left(\Delta S A L E_{i t}-\Delta R E C_{i t}\right)}{T A_{i t-1}}+\beta_{3}\left(\frac{P P E_{i t}}{T A_{i t-1}}\right)+\varepsilon_{i t}$

in which;

$N D A_{i t}=$ non-discretionary accruals for sample firm $i$ for year $t$

$T A_{i t-1}=$ total assets for sample firm $i$ for year $t$

$\triangle S A L E_{i t}=$ change in sales revenue for sample firm $i$ for year $t$

$\triangle R E C_{i t}=$ change in accounts receivable for sample firm $i$ for year $t$

$P P E_{i t}=$ property, plant and equipment for sample firm $i$ for year $t$

$\varepsilon_{i t}=$ error term for sample firm $i$ for year $t$

Having evaluated non-discretionary accruals (Equation 1), the amount of discretionary accruals for firm $i$ in year $t$ is computed as the residual value. Following previous research studies, this paper employs the absolute value of discretionary accruals as a measure for the degree of earnings management practices.

$$
D A C_{i t}=T A C_{i t}-N D A C_{i t}
$$

\subsection{Empirical Model}

In this section, the empirical model is presented. Independent variables are derived from previous literature (Gerayli et al., 2011; Krishnan, 2003; Dunn and Mayhew, 2004; Carcello and Neal, 2000; Davis et al., 2002). The primary rationale behind the choosing of research variables is that there is substantial agreement in the previous literature that the selected variables are very useful in analyzing the dynamics of earnings management practices. The use of appropriate research method prominently enhances the reliability of empirical analysis. Control variables (size, leverage and return on assets) are included in the empirical model. This study employs the following ordinary least regression model to test research hypotheses.

$$
\begin{gathered}
D_{i t}=\beta_{0}+\beta_{1} \text { AUDINDEP }_{i t}+\beta_{2} \text { AUDSPEC }_{i t}+\beta_{3} \text { AUDTEN }_{i t}+\beta_{4} \text { FIRMSIZE }_{i t} \\
+\beta_{5} \text { FIRMLEV }_{i t}+\beta_{6} \text { FIRMROA }_{i t}
\end{gathered}
$$

\begin{tabular}{|c|c|}
\hline$D A C_{i t}$ & Discretionary accruals of firm i for year $\mathrm{t}$ \\
\hline AUDINDEP $P_{i t}$ & $\begin{array}{l}\text { Auditor independence, a dummy variable takes the value of } 1 \text { if the firm is audited by } \\
\text { one of the Big- } 4 \text { auditors; otherwise } 0 \text {. }\end{array}$ \\
\hline$A U D S P E C_{i t}$ & $\begin{array}{l}\text { Audit specialization, a dummy variable takes the value of } 1 \text { if the industry market share } \\
\text { of the audit firm is greater than } 20 \% \text {; otherwise } 0 .\end{array}$ \\
\hline AUDTEN & $\begin{array}{l}\text { Audit tenure, a dummy variable takes } 1 \text { if the audit firm has audited the client firm's } \\
\text { financial statements for at least } 3 \text { years, otherwise } 0 .\end{array}$ \\
\hline FIRMSIZEit & Firm size, the natural logarithm of the total assets of sample firm i at the end of year $t$ \\
\hline FIRMLEV ${ }_{i t}$ & $\begin{array}{l}\text { Leverage ratio of sample firm i as ratio of total debts to total assets at the end of year } \\
t\end{array}$ \\
\hline FIRMROA $_{i t}$ & Return on assets of sample firm i defined as the ratio of net income to total assets. \\
\hline
\end{tabular}

Table 1 presents the definition of variables used in the empirical model.

Table 1: Variable Definition 


\subsection{Control Variables}

This paper incorporates several control variables, which are suggested by past research studies, that have prominent impacts on earnings management practices. The empirical model that includes control variables enables us to effectively test research hypotheses. In this study, size, leverage and return on assets are used as control variables.

Large firms are less likely to manage corporate earnings. This is because large firms draw more scrutiny from investors, creditors and stockholders (Chen et al., 2005; Zhou and Elder, 2001). Firm size can surrogate for some omitted variables. Ghosh and Moon (2010) and Gul et al. (2009) claim that firm size is negatively related with earnings management since large firms have wellestablished control systems that can effectively deter earnings management practices.

The degree of leverage influences earnings management practices. Sweeney (1994) and DeFond and Jiambalvo (1994) state that the highly leveraged firms' management can use discretionary accruals to meet debt covenant requirements. Firms heavily indebted may adopt income-increasing accounting practices in order to mitigate leverage ratio when negotiating with creditors.

Return on assets is included to control differences in sample firms' financial performance. The level of profitability plays vital role in firms' accounting choice. Habbash (2010) and Ashbaugh et al. (2003) state that return on assets is negatively correlated with earnings management. On the contrary, Ahn and Choi (2009) found no significant relationship between return on assets and earnings management.

\section{Empirical Results}

The results of empirical analysis are reported in this section. The sample consists of nonfinancial 97 firms listed on Borsa Istanbul. This study covers the accounting period between January 2013 and January 2018. Financial firms are not included in the sample due to the accounting rules that these firms follow in the preparation of financial statements are different. The empirical data is collected from the website of public disclosure platform that contains the financial statements of firms listed on Borsa Istanbul. Table 2 shows the industrial classifications of sample firms. The sample includes seven different industries, implying a broad distribution of industries. Food industry has the highest concentration with more than $21 \%$ of sample firms. In the sample, basic metal is the least represented industry (8.2\%). The sample contains 3395 firm-year observations.

Table 2: Industrial Classifications of Sample Firms

\begin{tabular}{lcc}
\hline Industry & Number of Firms & Percentage \\
\hline Food & 21 & 0.216 \\
Chemicals & 18 & 0.185 \\
Textiles & 16 & 0.164 \\
Electronics & 14 & 0.144 \\
Transportation & 11 & 0.113 \\
Constructions & 9 & 0.092 \\
Basic Metal & 8 & 0.082 \\
Total & 97 & $100 \%$ \\
\hline
\end{tabular}

The descriptive statistics of research variables employed in the sample are displayed in Table 3. As shown in Table 3, the absolute value of discretionary accruals of sample firms has a small mean value of 0.989 whereas the minimum value reaches 0.009 . These findings are consistent with Habbash and Alghamdi (2017) and Kao and Chen (2004). Generally speaking, Big-4 auditors charge higher audit fees. This is one of the reasons why only $24.5 \%$ of sample firms select Big- 4 auditors. 
24.1\% of sample firms select industry specialist auditors. More firms should select industry specialist auditors to improve the quality of financial reporting process. The mean value of auditor tenure is 0.439 , implying that $43.9 \%$ of sample firms are willing to be audited by the same auditor for at least 3 years.

Table 3 indicates that average firm size measured by the logarithm of total assets is 6.50 . The firm leverage, on average, is $59.6 \%$, suggesting that sample firms rely more on debt financing than equity financing. In other words, some of sample firms may face difficulties in paying their long term debts. Finally, table 3 shows that average return on assets of sample firms is 0.028 .

Table 3: Descriptive Statistics

\begin{tabular}{llllll}
\hline Variable & Obs. & Mean & Std. Dev. & Min. & Max. \\
\hline DAC & 485 & 0.989 & 0.680 & 0.009 & 2.87 \\
AUDINDEP & 485 & 0.245 & 0.430 & 0 & 1 \\
AUDSPEC & 485 & 0.241 & 0.428 & 0 & 1 \\
AUDTEN & 485 & 0.439 & 0.496 & 0 & 1 \\
FIRMSIZE & 485 & 6.506 & 2.331 & 3.18 & 12.98 \\
FIRMLEV & 485 & 0.596 & 1.324 & 0.001 & 0.78 \\
FIRMROA & 485 & 0.028 & 0.042 & 0.0015 & 0.332 \\
\hline
\end{tabular}

Notes: See table 1 for the definition of variables.

The Pearson correlation coefficients are presented for research variables in Table 4. The Pearson correlation coefficients enable us to elaborately analyze the association between independent and dependent variables. Table 4 indicates that discretionary accruals (DAC) is negatively associated with auditor independence, audit industry specialization and audit tenure. Audit quality measurements are moderately inter-correlated. Firm size is found to be positively and significantly correlated with all audit quality measurements.

Audit specialization and audit tenure are positively correlated at $p<0.05$ with auditor independence. Their correlation coefficients are $77 \%$ and $14 \%$ respectively. Return on assets is negatively correlated at $\mathrm{p}<0.10$ with discretionary accruals, indicating that firms with higher return on assets are less likely to manage corporate earnings. Multicollinearity may threaten the reliability of regression results if the Pearson correlations exceed 0.80 (Gujarati, 2003). As can be seen from Table 4, correlations are lower than 0.80 . It is worth mentioning that all of these correlations are created from univariate analysis, we should rely on the results of regression analysis that yields more reliable conclusions.

Table 4: Correlation Matrix

\begin{tabular}{llllllll}
\hline & \multicolumn{1}{c}{1} & \multicolumn{1}{c}{2} & \multicolumn{1}{c}{3} & \multicolumn{1}{c}{4} & 5 & 6 & 7 \\
\hline DAC (1) & 1.00 & & & & & & \\
AUDINDEP (2) & $-0.65^{*}$ & 1.00 & & & & & \\
AUDSPEC (3) & $-0.63^{*}$ & $0.77^{* *}$ & 1.00 & & & & \\
AUDTEN (4) & $-0.17^{*}$ & $0.14^{* *}$ & $0.16^{*}$ & 1.00 & & & \\
FIRMSIZE (5) & $-0.70^{*}$ & $0.59^{*}$ & $0.55^{*}$ & $0.32^{*}$ & 1.00 & & \\
FIRMLEV (6) & 0.02 & 0.03 & 0.04 & 0.03 & 0.02 & 1.00 & \\
FIRMROA (7) & $-0.58^{*}$ & $0.72^{*}$ & $0.64^{*}$ & $0.15^{*}$ & $0.56^{*}$ & 0.06 & 1.00 \\
\hline
\end{tabular}

Notes: $* *, * *$, and $*$ indicate significance at the 1,5 , and 10 percent levels, see Table 1 for the definition of variables.

Table 5 displays the results of ordinary least regression. As indicated in Table 5 , there is a significant negative relationship between discretionary accruals and auditor independency, 
confirming the findings of Gerayli et al. (2011) and Hodge (2003). It can be inferred that an increase in auditor independency decreases the likelihood of earnings management. This result also indicates that regulatory agencies should take necessary actions to enhance auditor independency to improve the reliability of financial statements. Hypothesis 1 that there is a negative relationship between auditor independence and earnings management practices is accepted.

The relationship between discretionary accruals and audit specialization is significantly negative at the 0.01 level. This result supports the findings of Dunn and Mayhew (2004) and Zhou and Elder (2001). Industry specialist auditors are more likely to reduce earnings management practices and, thereby increasing the credibility of financial reporting process. Hypothesis 2 that there is a negative relationship between audit industry specialization and earnings management practices is accepted.

The regression results also show a positive association between discretionary accruals and auditor tenure. The insignificant association between discretionary accruals and auditor tenure purports that auditor tenure is not effective in mitigating earnings management practices. This result is inconsistent with those found by Davis et al. (2002) and Ghosh and Moon (2005). Long auditor tenure may cause broad familiarity between the auditor and client, which can decrease the objectivity and independence of auditors. The result supports the assertion that longer audit tenure may erode the quality of financial reporting process. Hypothesis 3 that there is a negative relationship between audit tenure and earnings management practices is rejected.

Firm size is found to be negatively associated with discretionary accruals, implying that smallsized firms are more likely to engage in earnings management. This may be because large-sized firms have more effective internal control systems than those of small-sized firms. This is similar to findings of Chen et al. (2005), Zhou and Elder (2001), Ghosh and Moon (2005) and Gul et al. (2009). A positive relationship between firm leverage and discretionary accruals is found but it is insignificant. This result supports the theory that highly leveraged firms are more likely to artificially increase corporate earnings to enhance their bargaining power during the debt settlement. This result is in line with the findings of Sweeney (1994) and DeFond and Jiambalvo (1994). The regression results indicate that coefficient on return on assets is negative and significant at the 0.10 level. This finding reveals that firms experiencing poor financial performance have much more incentive to manage earnings. The management of a firm experiencing poor financial performance can artificially inflate earnings to meet its financial obligations. This result is inconsistent with the findings of Habbash (2010) and Ashbaugh et al. (2003). Adjusted R-squared value reported in table 5 reveals that the empirical model explains the $59 \%$ of variation in discretionary accruals.

Table 5: Regression Results

\begin{tabular}{lcc}
\hline Variables & Coefficient & t-value \\
\hline AUDINDEP & -0.226 & $-2.29^{* *}$ \\
AUDSPEC & -0.289 & $-3.24^{* * *}$ \\
AUDTEN & 0.053 & 1.27 \\
FIRMSIZE & -0.138 & $-12.23^{* * *}$ \\
FIRMLEV & 0.015 & 1.07 \\
FIRMROA & -1.760 & $-2.52^{* *}$ \\
Constant & 2.030 & $31.16^{* * *}$ \\
Adjusted R-Squared & 0.59 & \\
p-value of F-test & 0.00 & \\
\hline
\end{tabular}

Notes: $* * *, * *$, and $*$ indicate significance at the 1,5 , and 10 percent levels, see table 1 for the definition of variables. 


\section{Concluding Remarks}

In the current business climate, earnings management is a great concern for creditors, stockholders, investors and government agencies. Earnings management seems to remain a highly debated topic among financial market participants in the future. Low quality of earnings has been masked by earnings management practices. Higher market expectations may drive firms to engage in earnings management. In the competitive business environment firms should focus on strengthening the abilities of audit committee that enhances the quality of financial reporting process. Auditors have prominent functions in guaranteeing the credibility of firms' financial statements. Increasing audit quality concerns present new challenges and opportunities for audit firms. It is also worth mentioning that an effective internal control system significantly boosts the quality of financial statements disclosed to the public.

Using a sample that includes 97 non-financial firms listed on Borsa Istanbul from 2013 to 2018, the results of empirical analysis indicate that industry specialist auditors are more likely to detect earnings management practices and longer audit tenure is related with higher probability of earnings management practices. Additionally, the results of empirical analysis reveal that a highlevel of auditor independence considerably constrains earnings management practices. Firm size, leverage and return on assets are used as control variables to effectively test research hypotheses. The negative coefficient on firm size indicates that large firms are less likely to engage in earnings management. The results of empirical analysis are consistent with the notion that firms suffering from liquidity problems have much more incentive to engage in earnings management. The empirical model also suggests that firms which have lower financial performance are likely to adopt accounting choices that can artificially corporate earnings.

Taken together, the results of empirical analysis demonstrate that discretionary accruals may be used to manipulate financial statements and mislead creditors, investors and stockholders. Deterioration in audit quality has adverse impacts on the economic environment. Regulatory agencies should take actions that enhance audit quality. The results of empirical analysis provide important implications to regulatory agencies, audit firms, investors and standard setting bodies.

\section{References}

Ahn, S., and Choi, W. (2009). The Role of Bank Monitoring in Corporate Governance: Evidence from Borrowers' Earnings Management Behaviour. Journal of Banking \& Finance, 33(2), 425434.

Antle, R. (1984). Auditor Independence. Journal of Accounting Research, 22 (1), 1-20.

Ashbaugh, H., LaFond, R., and Mayhew, B. W. (2003). Do Non-Audit Services Compromise Auditor Independence? Further Evidence. The Accounting Review, 78(3), 611-639.

Balsam, S., Krishnan, J., and Yang, J. S. (2003). Auditor Industry Specialization and Earnings Quality. Auditing: A Journal of Practice \& Theory, 22(2), 71-97.

Beattie, v., Brandt, R. and Fearnley, S. (1999). Perceptions of Auditor Independence: UK Evidence. Journal of International Accounting, Auditing and Taxation, 8(1), 67-107.

Beck, P. J., Frecka, T. J., and Solomon, I. (1988). An Empirical Analysis of the Relationship Between MAS Involvement and Auditor Tenure: Implications for Auditor Independence. Journal of Accounting Literature, 7(1), 65-84.

Becker, C. L., DeFond, M. L., Jiambalvo, J., and Subramanyam, K. R. (1998). The Effect of Audit Quality on Earnings Management. Contemporary Accounting Research, 15(1), 1-24.

Carcello, J. V., and Neal, T. L. (2000). Audit Committee Composition and Auditor Reporting. The Accounting Review, 75(4), 453-467. 
Chen, K. Y., Lin, K. L., and Zhou, J. (2005). Audit Quality and Earnings Management for Taiwan IPO firms. Managerial Auditing Journal, 20(1), 86-104.

Chi, W., Douthett Jr, E. B., and Lisic, L. L. (2012). Client importance and audit partner independence. Journal of Accounting and Public Policy, 31(3), 320-336.

Craswell, A. T., Francis, J. R., and Taylor, S. L. (1995). Auditor Brand Name Reputations and Industry Specializations. Journal of Accounting and Economics, 20(3), 297-322.

Davis, L. R., B. Soo, and G. Trompeter. (2002). Auditor Tenure, Auditor Independence and Earnings Management. Working Paper, Boston College, Boston.

DeAngelo, L. E. (1981). Auditor Size and Audit Quality. Journal of Accounting and Economics, 3(3), 183-199.

Dechow, P. M., and Skinner, D. J. (2000). Earnings Management: Reconciling the Views Of Accounting Academics, Practitioners, and Regulators. Accounting Horizons, 14(2), $235-$ 250.

DeFond, M. L., and Francis, J. R. (2005). Audit Research After Sarbanes-Oxley. Auditing: A Journal of Practice \& Theory, 24(s-1), 5-30.

DeFond, M. L., and Park, C. W. (1997). Smoothing Income in Anticipation of Future Earnings. Journal of Accounting and Economics, 23(2), 115-139.

DeFond, M. L., and Jiambalvo, J. (1994). Debt Covenant Violation and Manipulation of Accruals. Journal of Accounting and Economics, 17(1-2), 145-176.

Dunn, K. A., and Mayhew, B. W. (2004). Audit Firm Industry Specialization and Client Disclosure Quality. Review of Accounting Studies, 9(1), 35-58.

Gerayli, M. S., Yanesari, A. M., and Ma'atoofi, A. R. (2011). Impact of Audit Quality on Earnings Management: Evidence from Iran. International Research Journal of Finance and Economics, 66(1), 77-84.

Ghosh, A., and Moon, D. (2005). Auditor Tenure and Perceptions of Audit Quality. The Accounting Review, 80(2), 585-612.

Gill G, and Cosserat G.. (1996). Modern Auditing in Australia, Fourth Edition Wiley and Sons Australia.

Gujarati, D. (2003). Basic Econometrics (4th ed.). New York: McGraw Hill.

Gul, F. A., Chen, C. J., and Tsui, J. S. (2003). Discretionary Accounting Accruals, Managers' Incentives, and Audit Fees. Contemporary Accounting Research, 20(3), 441-464.

Gul, F. A., Fung, S. Y. K., and Jaggi, B. (2009). Earnings Quality: Some Evidence on the Role of Auditor Tenure and Auditors' Industry Expertise. Journal of Accounting and Economics, 47(3), 265287.

Habbash, M. (2010). The Effectiveness of Corporate Governance and External Audit on Constraining Earnings Management Practice in the UK (Doctoral dissertation, Durham University).

Habbash, M., and Alghamdi, S. (2017). Audit Quality and Earnings Management in Less Developed Economies: The Case of Saudi Arabia. Journal of Management \& Governance, 21(2), 351373.

Hodge, F. D. (2003). Investors' Perceptions of Earnings Quality, Auditor Independence, and the Usefulness of Audited Financial Information. Accounting Horizons, 17, 37-48. 
Houghton, K., and Jubb, C. (2003). Market Competition and Auditor Independence. Agenda: A Journal of Policy Analysis and Reform, 10(3), 213-228.

Hunt, A. K., and Lulseged, A. (2007). Client importance and non-Big 5 auditors' reporting decisions. Journal of Accounting and Public Policy, 26(2), 212-248.

Hunton, J. E., Libby, R., and Mazza, C. L. (2006). Financial Reporting Transparency and Earnings Management. The Accounting Review, 81(1), 135-157.

Kao, L., and Chen, A. (2004). The Effects of Board Characteristics on Earnings Management. Corporate Ownership \& Control, 1(3), 96-107.

Krishnan, G. V. (2003). Audit Quality and the Pricing of Discretionary Accruals. Auditing: A Journal of Practice \& Theory, 22(1), 109-126.

Lin, J. W., Li, J. F., and Yang, J. S. (2006). The Effect of Audit Committee Performance on Earnings Quality. Managerial Auditing Journal, 21(9), 921-933.

Magee, R. P., and Tseng, M. C. (1990). Audit pricing and independence. Accounting Review, 65(2), 315-336.

Mansi, S. A., Maxwell, W. F., and Miller, D. P. (2004). Does Auditor Quality and Tenure Matter to Investors? Evidence from the Bond Market. Journal of Accounting Research, 42(4), 755793.

Sweeney, A. P. (1994). Debt-Covenant Violations and Managers' Accounting Responses. Journal of Accounting and Economics, 17(3), 281-308.

Tepalagul, N., and Lin, L. (2015). Auditor Independence and Audit Quality: A Literature Review. Journal of Accounting, Auditing \& Finance, 30(1), 101-121.

Zhou, J., and Elder, R. (2001). Audit Firm Size, Industry Specialization and Earnings Management by Initial Public Offering Firms. Working paper, State University of New York at Binghamton. 
